\title{
Cyst and radionucleotide evidence for the recent introduction of the toxic dinoflagellate Gymnodinium catenatum into Tasmanian waters
}

\author{
Andrew McMinn ${ }^{1, *}$, Gustaaf M. Hallegraeff ${ }^{2}$, Paul Thomson ${ }^{1}$, \\ Andrew V. Jenkinson ${ }^{3}$, Henk Heijnis ${ }^{3}$ \\ ${ }^{1}$ Institute of Antarctic and Southern Ocean Studies, University of Tasmania, GPO Box 252-77, Hobart, \\ Tasmania 7001, Australia \\ ${ }^{2}$ Department of Plant Science, University of Tasmania, GPO Box 252-55, Hobart, Tasmania 7001, Australia \\ ${ }^{3}$ Environmental Radiochemistry Laboratory, Australian Nuclear Science and Technology Organisation, Private Mailbag 1 , \\ Menai, New South Wales 2234, Australia
}

\begin{abstract}
Cysts of the dinoflagellate Gymnodinum catenatum were present only in the top sections of duplicate marine sediment cores from Deep Bay in southern Tasmania, Australia. ${ }^{210} \mathrm{~Pb}$ and ${ }^{137} \mathrm{Cs}$ analyses indicate that the appearance of the cyst of this toxic dinoflagellate (one of the causative organisms of paralytic shellfish poisoning) occurred after 1972. This sedment core evidence and the absence of this species from the phytoplankton of most other neighbourng Australian waters suggest that Gymnodinium catenatum is not endemic to Tasmania but has been introduced recently. This species was first seen in bloom proportions in Tasmania in 1980, with major blooms having occurred since then in 1986, 1991 and 1993. Several lines of evidence suggest that ballast water discharge from cargo vessels originating from Japan and South Korea, or less likely Europe, is the most probable mechanism of introduction.
\end{abstract}

KEY WORDS: Gymnodinium catenatum - Sediment cysts - Ballast water introduction - Radiometric dating

\section{INTRODUCTION}

Blooms of the toxic dinoflagellate Gymnodinium catenatum Graham were first recognised in southern Tasmanian waters in late 1985 (Hallegraeff \& Sumner 1986, Hallegraeff et al. 1989). Soon after, commercial shellfish from the Derwent and Huon River estuaries proved to be contaminated with high concentrations of paralytic shellfish poisons (Oshima et al. 1987). However, in years when water temperature, rainfall and windstress were unfavourable for blooms of this species, it remained only a minor component of the phytoplankton (Hallegraeff et al. 1995). The question arose as to whether $G$. catenatum was a recent introduction into the area or whether it had occurred there previ-

\footnotetext{
-E-mail: andrew.mcminn@utas.edu.au
}

ously in low concentrations without actually having been recorded. If it had been present prior to the events in the past decade, its sudden mass occurrence in the last 20 yr could perhaps be related to a change in environmental conditions favourable for the growth of this dinoflagellate. However, $G$. catenatum is a conspicuous, large (23 to $41 \mu \mathrm{m}$ long, 27 to $36 \mu \mathrm{m}$ wide), chain-forming dinoflagellate (up to 64 cells long), which is readily collected by plankton nets and which preserves even when using harsh fixatives such as formaldehyde. A survey of historic plankton samples and data collected by workers at the University of Tasmania (D. P. Thomas), the Electrolytic Zinc Company, Tasmania (W. Ball), and the CSIRO Division of Fisheries \& Oceanography (Wood 1964) indicated that there is no evidence that the organism had been in Tasmanian waters in the periods 1945-1950 and 1975-1978, and first appeared in the Derwent River in 


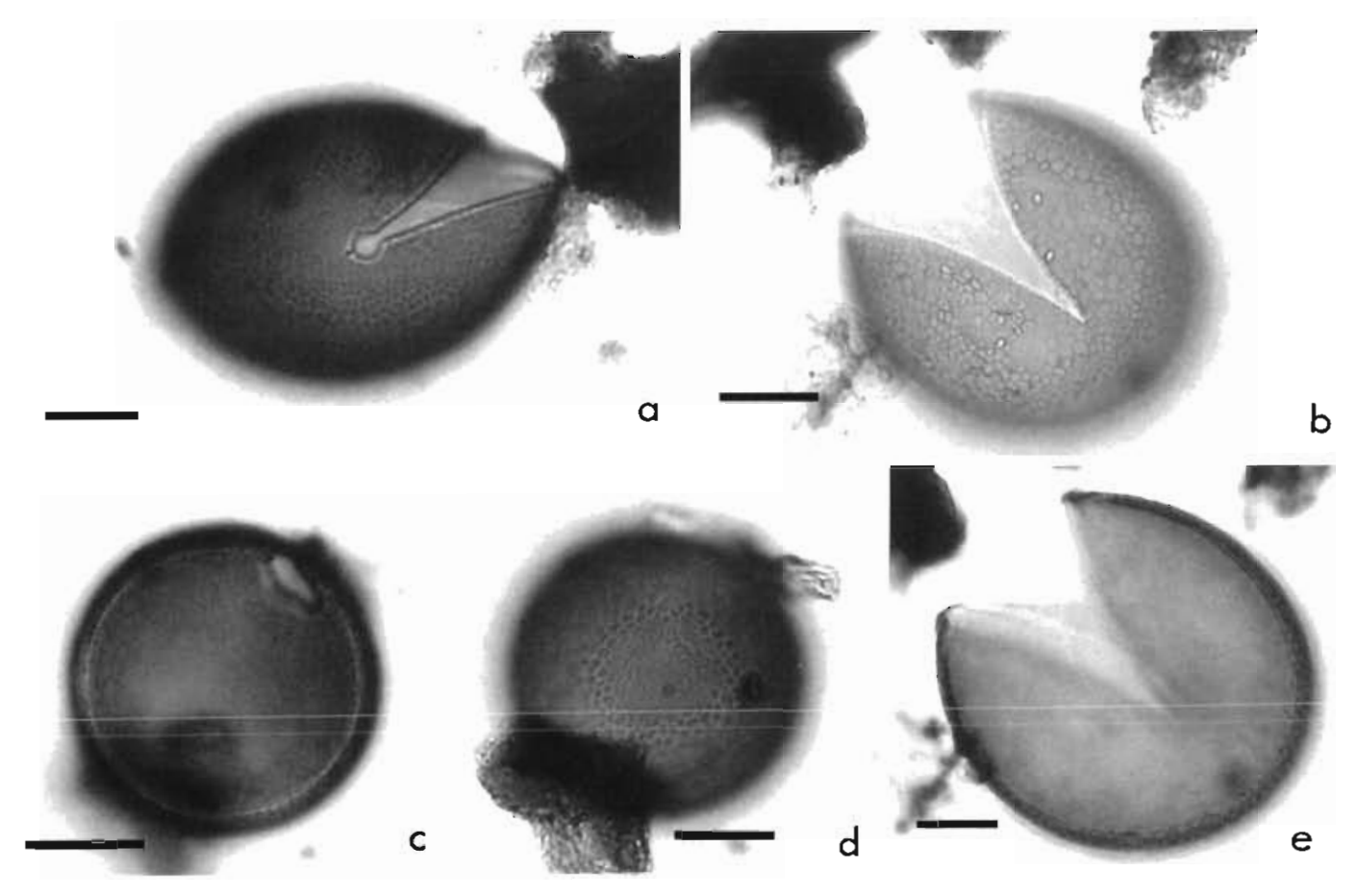

Fig. 1. Gymnodinium catenatum. Light micrographs of cysts from Deep Bay, Tasmania, showing paracingular excystment aperture (chasmic archeopyle) and fine reticulate surface ornamentation. Scale bars $=10 \mu \mathrm{m}$

1980. A concomitant survey of local hospital records confirmed that suspected human poisonings after shellfish consumption had occurred as early as 1980 . but not before that date (Hallegraeff et al. 1988). Furthermore, there is no tradition of human poisonings among Aboriginal tribes that lived in the area prior to European colonisation and which consumed large quantities of shellfish (Jones 1978)

As part of its life cycle, the dinoflagellate Gymnodinium catenatum produces a resistant, brown, spherical resting cyst with a fine, microreticulate surface ornamentation (Fig. 1) (Anderson et al. 1988, Blackburn et al. 1989). A Tasmania-wide survey of coastal sediments found abundant, viable $G$. catenatum resting cysts in the Huon and Derwent River estuaries (Bolch \& Hallegraeff 1990). Sparse cyst beds were also recorded from the east coast of Tasmania, from Spring Bay (Triabunna) and Georges Bay (St Helens) (Fig. 2), but no motile dinoflagellates or shellfish toxicity have been detected at these locations. This cyst, which can withstand palynological treatment (Anderson et al. 1988, Nordberg \& Bergsten 1988), has never been observed in prehistoric Australian sediments (McMinn $1989,1992 \mathrm{a}, \mathrm{b})$. It was also absent in a survey of Recent sediments from the entire east coast of mainland Australia (McMinn 1990, 1991) and from New Zealand (Baldwin 1987). Recently, however, G. catenatum cysts have been detected in sediments, from Warrnambool and Lorne, Victoria (Sonneman \& Hill 1997), and from Port Lincoln, South Australia (Hallegraef unpubl. data).

\section{MATERIALS AND METHODS}

Duplicate sediment cores (15 to $25 \mathrm{~cm}$ long, $4.5 \mathrm{~cm}$ diameter) were collected in September 1991 from Deep Bay in southern Tasmania, Australia, using a modified Craib corer (Craib 1965). Further cores were collected from the same site in October $1994(80 \mathrm{~cm}$ long, $11 \mathrm{~cm}$ diameter) using an Impact corer (Neale \& Walker 1996) and in June 1995 [21 cm long, $11 \mathrm{~cm}$ diameter using a Glew corer (Glew 1989)]. Deep Bay is an $18 \mathrm{~m}$ deep, sheltered embayment near the mouth of the Huon River, Tasmania (Fig 2). The 1991 cores were stored in the dark at $4^{\circ} \mathrm{C}$ prior to examination. One core was frozen in liquid nitrogen and partitioned into $2 \mathrm{~cm}$ intervals for ${ }^{210} \mathrm{~Pb}$ dating. Samples from the second core were partitioned into $1 \mathrm{~cm}$ intervals and sent to Laola Pty Ltd, Western Australia, for palynological processing. This involved disaggregation in $\mathrm{HF}$, density separation in a $\mathrm{ZnBr}_{2}$ solution (specific gravity 2.1), sieving on an 8 um filter, and mounting in a permanent mounting medium (Eukitt). For the 1994 core, samples for ${ }^{210} \mathrm{~Pb}$ and dinoflagellate analysis were taken from the same core. Samples for 

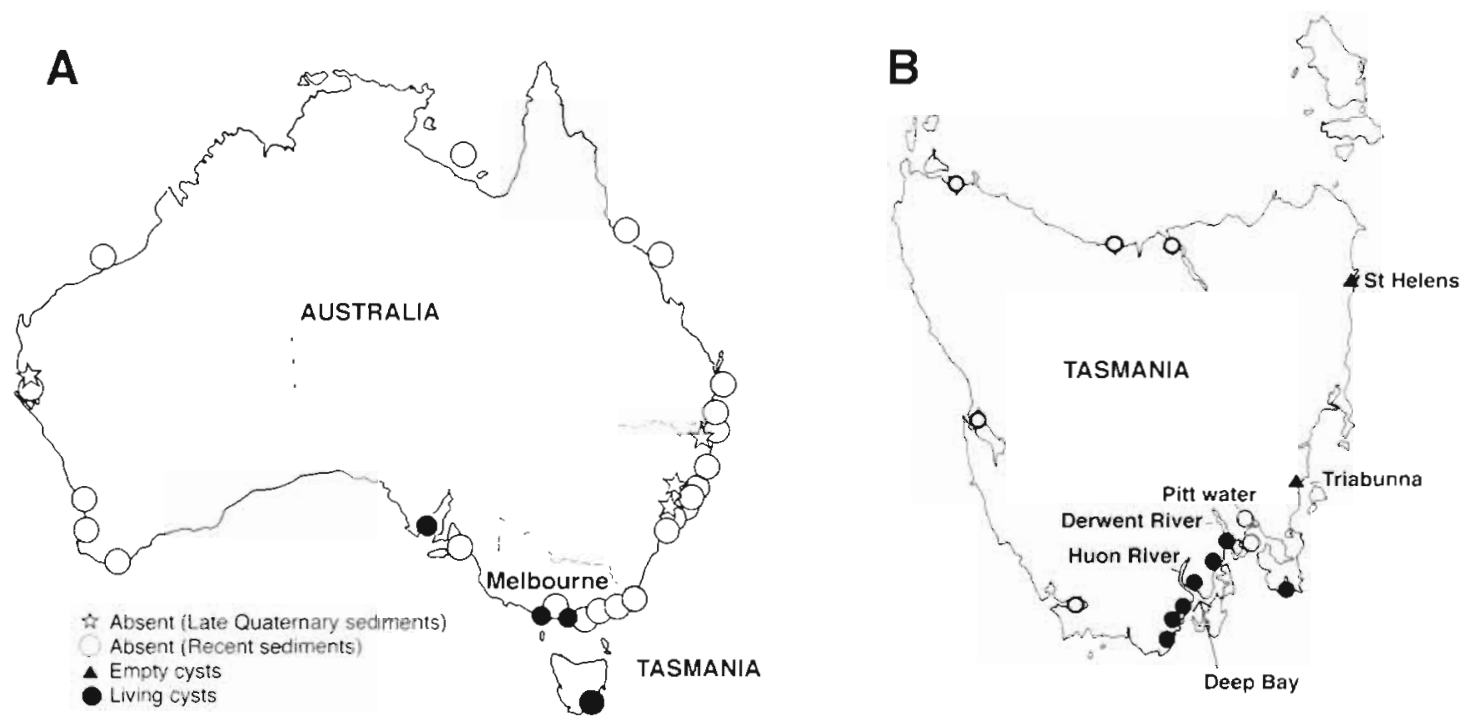

Fig. 2. (A) Australia showing the location of (B) Tasmania and Deep Bay. The presence or absence of cysts of Gymnodinium catenatum in sediments has been summarised (based on various sources including Bolch \& Hallegraeff 1990, McMinn 1991 and B. Dale pers. comm.)

${ }^{137} \mathrm{Cs}$ analysis were taken from the Glew core collected in 1995. Slides prepared for dinoflagellate cyst analysis were examined with a Zeiss Axioskop microscope and estimates of dinoflagellate cyst abundance were made from 3 replicate counts of 400 specimens (see Table 1).

Samples for ${ }^{210} \mathrm{~Pb}$ analysis were dried at $105^{\circ} \mathrm{C}$ to constant weight and ground to pass through a $150 \mu \mathrm{m}$ sieve. Approximately $5 \mathrm{~g}$ was weighed into a beaker and ${ }^{209} \mathrm{Po}$ and ${ }^{133} \mathrm{Ba}$ yield tracers added. $25 \mathrm{ml}$ of concentrated $\mathrm{HNO}_{3}$ was added and evaporated until dry in order to eliminate most organic matter. $25 \mathrm{ml}$ of $10 \%$ $\mathrm{H}_{2} \mathrm{O}_{2}$ was then added and the beaker returned to a water bath until effervescence ceased, to oxidise the remaining organic matter. $25 \mathrm{ml}$ of concentrated $\mathrm{HCl}$ was then added and the mixture refluxed on the water bath for 4 to $6 \mathrm{~h}$. The mixture was cooled and the residue removed by centrifugation. Excess Fe was removed by diethyl ether extraction and the solution evaporated until dry. The residue was then dissolved in $50 \mathrm{ml}$ of $0.1 \mathrm{M} \mathrm{HCl}$ and ${ }^{210} \mathrm{Po}\left(+{ }^{209} \mathrm{Po}\right)$ autodeposited onto a silver disk. $1 \mathrm{~g}$ of hydroxylamine hydrochloride $\left(\mathrm{NH}_{2} \mathrm{OH} \cdot \mathrm{HCl}\right)$ was used as the reductant and $100 \mathrm{ml}$ 1.0 M citric acid added to complex trace Fe and $\mathrm{Cr}$. The silver disk was then subjected to alpha spectrometry and the spent solution was diluted to $900 \mathrm{ml}$, and $20 \mathrm{ml}$ of concentrated $\mathrm{H}_{2} \mathrm{SO}_{4}$ and $100 \mathrm{ml}$ of saturated $\mathrm{Na}_{2} \mathrm{SO}_{4}$ were added. Radium and barium were coprecipitated with $\mathrm{PbSO}_{4}$ carrier. The supernatant was removed by suction and the $\mathrm{Pb} / \mathrm{BaSO}_{4}$ residue washed with $50 \%$ ethanol which is then discarded after centrifugation. The precipitate was then dissolved in $5 \mathrm{ml}$ of alkaline
DTPA ( $\mathrm{pH} \mathrm{9.5)} \mathrm{and} \mathrm{the} \mathrm{pH}$ readjusted to $>9$. The solution was filtered through a $0.45 \mu \mathrm{m}$ filter and the filter rinsed with $5 \mathrm{ml}$ of $4 \% \mathrm{Na}_{2} \mathrm{SO}_{4}$. Two drops of methyl red and $2 \mathrm{ml}$ of glacial acetic acid were added. Immediately after, $1 \mathrm{ml}$ of a colloidal $\mathrm{BaSO}_{4}$ seeding suspension was added and the solution left for $30 \mathrm{~min}$. The colloidal $\mathrm{Ba} / \mathrm{RaSO}_{4}$ precipitate was collected on a Millipore fluoropolymer filter and air-dried. Barium and radium recovery were estimated by submitting the membrane filter to gamma spectrometry on a HPGe gamma detector. ${ }^{226} \mathrm{Ra}$ was estimated by alpha spectrometry of the filter source.

${ }^{137} \mathrm{Cs}$ measurements were made by gamma spectrometry on a compton suppressed HPGe detector using petri dishes for source geometry.

\section{RESULTS}

\section{Dinoflagellate cysts}

Sediment cores taken from Deep Bay in southern Tasmania contained a sequence of unlaminated black muds with no obvious evidence of either stratification or bioturbation. Relative abundances of dinoflagellate cysts in the 1991 and 1994 cores are summarised in Table 1. Dinoflagellate cyst assemblages in both cores were dominated by the cysts of Protoceratium reticulatum (= Operculodinium centrocarpum) (89.0 to $97.1 \%$ of total cysts, range over both cores), which increased in abundance from $1 \times 10^{6} \mathrm{~g}^{-1}$ at the surface to $5 \times 10^{6}$ $\mathrm{g}^{-1}$ sediment at $80 \mathrm{~cm}$ depth. Cysts of Gonyaulax 
Table 1. Distribution of dinoflagellate cysts with depth in the 1991 and 1994 sediment cores from Deep Bay, Tasmania. All abundances are given as percentage abundance. Names in parentheses are palaeontological names

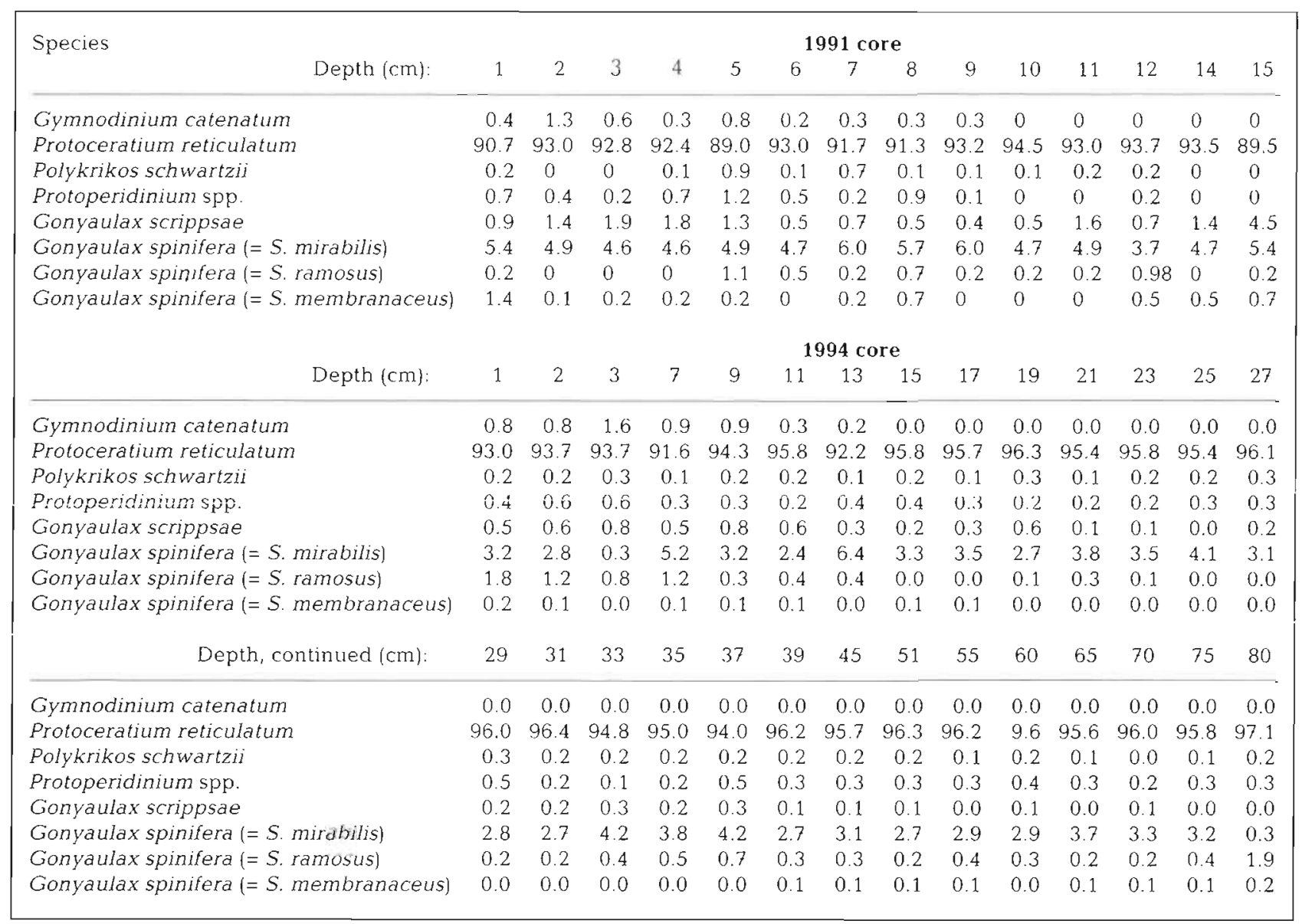

spinifera (= Spiniferites mirabilis) were common $(0.3$ to $6.4 \%$, over both cores), while other species such as Polykrikos schwartzii, Protoperidinium conicum, Protoperidinium oblongum, Gonyaulax scrippsae (= Spiniferites bulloideus) and Gonyaulax spinifera (= Spiniferites membranaceus and Spiniferites ramosus) were rare. The cysts of Gymnodinium catenatum were a rare 10 to $1.6 \%$ of total cysts, range for both cores) but consistent element in all cyst assemblages from the surface down to a depth equivalent to 1972 (i.e. $9 \mathrm{~cm}$ in the 1991 core and $13 \mathrm{~cm}$ in the 1994 core). They were virtually absent, however, from assemblages deposited prior to that time (Fig 3). There is a trailing, low frequency of $G$. catenatum cysts down to $31 \mathrm{~cm}$ (equivalent to $1937 \pm 6 \mathrm{yr}$ ) in the 1994 core but this almost certainly represents local bioturbation at the time of introduction (i.e. minor bioturbation to a depth of $18 \mathrm{~cm}$ at the time when sediment at $13 \mathrm{~cm}$ in the core, or $1972 \pm 2 \mathrm{yr}$, was being deposited). There are no cysts older than $1972 \pm 2$ yr in the 1991 core or older than $1937 \pm 6$ yr in the 1994 core (Fig. 3).

\section{Sediment isotope studies}

The sediment cores from Deep Bay were analysed using $2^{210} \mathrm{~Pb}$ dating models. The more simple CIC (i.e. Constant Initial Concentration) model assumes a constant sedimentation rate as well as a constant flux of excess ${ }^{210} \mathrm{~Pb}$. Therefore, a plot of the log of unsupported ${ }^{210} \mathrm{~Pb}$ (i.e. excess ${ }^{210} \mathrm{~Pb}$ originating from the atmosphere) against depth should yield a straight line (Fig. 4). The slope of this line is a measure of the sedimentation rate. The CRS (Contant Rate of Supply) model assumes a constant rate of supply of ${ }^{210} \mathrm{~Pb}$ to the surface and sedimentation rates are calculated at each point in time. This method allows for changes in sedimentation rate within a profile with a constant supply of ${ }^{210} \mathrm{~Pb}$ (Oldfield \& Appleby 1984). The 2 models predict similar ages for the top $33 \mathrm{~cm}$ of the core , below this a deviation is visible for the CIC model due to uncertainties in the average sedimentation rate (Fig. 4).

The ${ }^{137} \mathrm{Cs}$ data (Fig. 5) show a maximum input around $7 \mathrm{~cm}$ depth, or 1981 However, only 1 to $2 \%$ of 


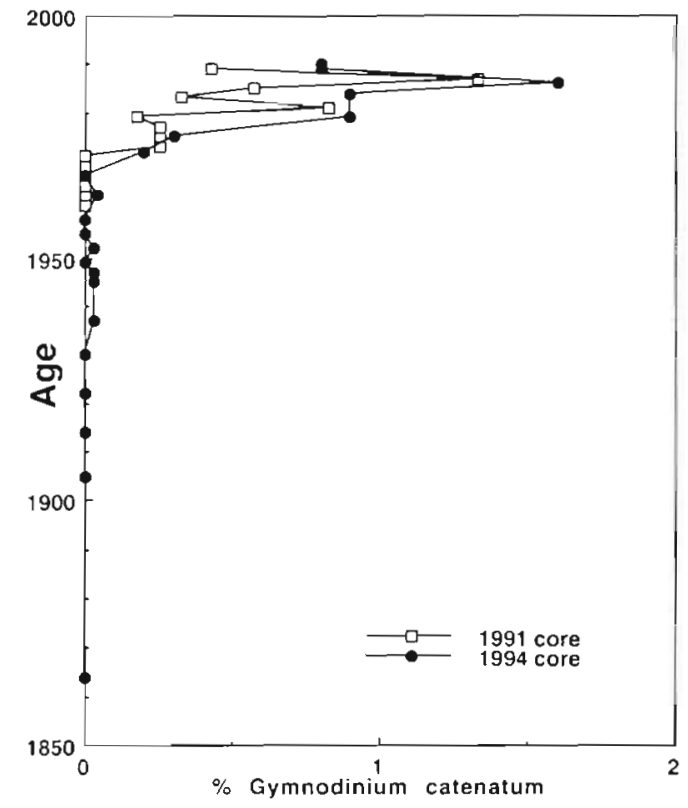

Fig. 3. Gymnodinium catenatum. Abundance of cysts (expressed as percentage of total dinoflagellate cysts) with date for 2 sediment cores from Deep Bay, Tasmania

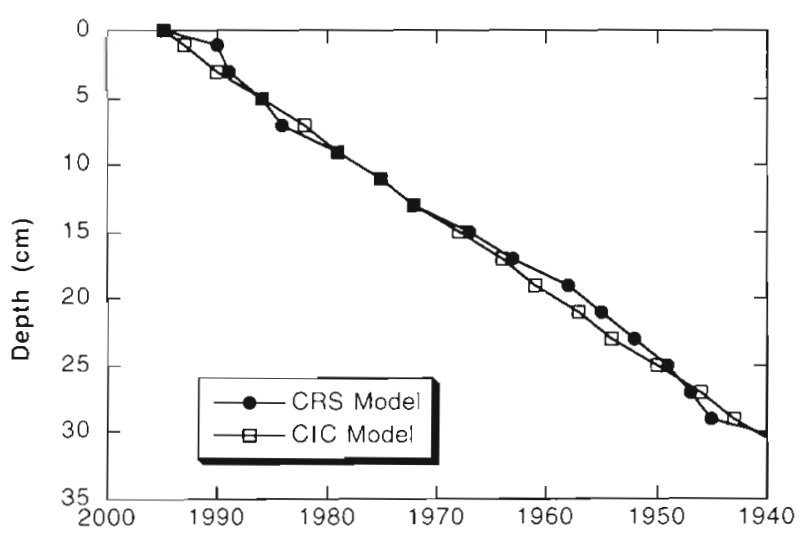

Fig. 4. Age interpretation with depth in the 1994 core. The interpretations are based on the Constant Rate of Supply

(CRS) and Constant Initial Concentration (CIC) models

the ${ }^{137} \mathrm{Cs}$ in the sediments at the Deep Bay site would have resulted from direct atmospheric fallout at the site. Most of the ${ }^{137} \mathrm{Cs}$ is likely to have been transported from the catchment area by attachment to clay minerals (Eakins et al. 1984). Landuse changes in the catchment, such as changing logging practices, lead to a pulse release of ${ }^{137} \mathrm{Cs}$ into local streams and thence into an estuarine depositional site (Eakins et al. 1984, Zuo 1992). The pulse of ${ }^{137} \mathrm{Cs}$ in the Deep Bay core cannot be attributed to the normal peak in atmospheric fallout as a results of atmospheric testing, which occurred in

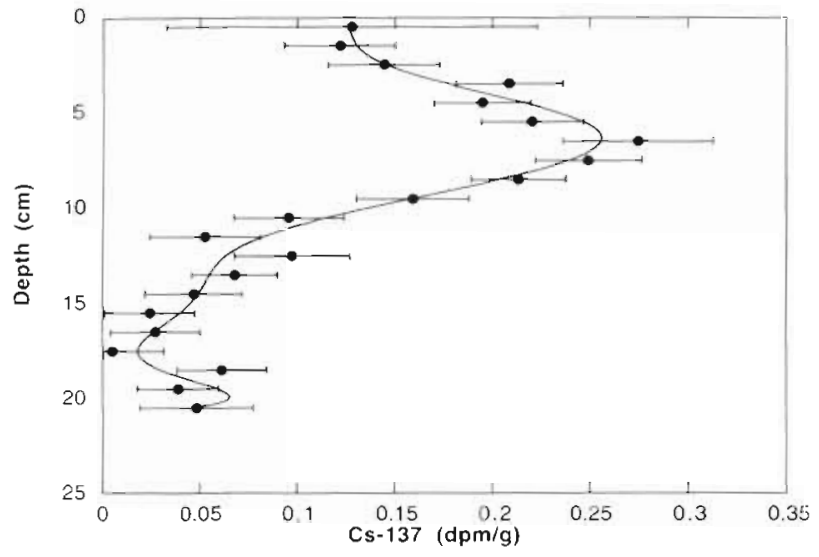

Fig. 5. Distribution of ${ }^{137} \mathrm{Cs}$ with depth in the 1995 core

the early 1960s, but to changed landuse patterns (probably increased logging in the Huon catchment during the $1970-80$ s). Therefore the peak in ${ }^{137} \mathrm{Cs}$ in the Huon cores can be used to investigate the extent of sediment mixing. The pulsed profile indicates that sediment mixing has not been significant and so the ${ }^{210} \mathrm{~Pb}$ sedimentation rate estimates are reliable.

\section{DISCUSSION}

The monitoring of recent environmental change in coastal waters and estuaries by examining the changing proportions of dinoflagellates cysts in sediment cores is a comparatively new field of study (Dale 1989). McMinn (1990, 1991) showed that dinoflagellate cyst assemblages from estuaries in eastern Australia reflected impacts of urbanisation and agricultural sunoff. The unvarying relative abundance of the dominant dinoflagellate species Protoceratium reticulatum $(=O p-$ erculodinium centrocarpum) and Gonyaulax spinifera (= Spiniferites mirabilis) throughout the Deep Bay sediment cores suggests that little major environmental change has occurred in this estuary over the last $60 \mathrm{yr}$. The appearance of cysts of Gymnodinium catenatum at $9 \mathrm{~cm}$ in the 1991 core and at $13 \mathrm{~cm}$ in the 1994 core therefore, in all likelihood, does not reflect a response to changing environmental conditions but a recent introduction event. ${ }^{210} \mathrm{~Pb}$ and ${ }^{137} \mathrm{Cs}$ data provide a date of approximately 1972 for this introduction.

It is significant that the cyst-forming dinoflagellate species accompanying Gymnodinium catenatum in Deep Bay (Table 1) are significantly different from the species accompanying $G$. catenatum in Japan (Matsuoka \& Fukuyo 1994). This evidence, combined with the very restricted distribution of $G$. catenatum in Tasmania (Fig. 2) and much wider distribution in warm temperate waters of southern Japan (Yat- 
sushiro Sea to Seto Inland. Sea, and Wakasa Bay), lends further support to the suggestion that this species is exotic to Tasmania. The absence in the Tasmanian cyst assemblages of the warm-water species Operculodinium israelianum (microfossil name as there is no known biological equivalent), Pyrophacus vancampoae and Lingulodinium hemicystum (microfossil name as there is no known biological equivalent) agrees with the climatological gradients proposed by McMinn (1990).

Cysts of the dinoflagellate Alexandrium tamarense have a half life in anoxic sediments of approximately 5 yr (Keafer et al. 1992) but there is no similar information available for the more fragile Gymnodinium catenatum, although it is likely to be similar. Empty dinoflagellate cysts can survive in sediments for extremely long periods of time. The oldest known dinoflagellate cyst is approximately 420 million yr old (Sarjeant 1974) and cysts of Triassic age (approximately 200 to $250 \mathrm{mil}$ lion yr) and younger are common (Evitt 1985). The oldest cysts of $G$. catenatum are approximately 6000 yr old (Nordberg \& Bergsten 1988), demonstrating that these cysis call survive for long perlods of time without degrading. It also confirms that the disappearance of $G$. catenatum cysts in the Huon River cores is due to an introduction event and is not a result of progressive degradation over time.

Two transport vectors could have played a role in the introduction of Gymnodinium catenatum into Tasmanian waters: (1) associated with the introduction of Japanese shellfish stocks or (2) discharge via ships' ballast water. The Pacific oyster Crassostrea gigas was introduced into Tasmania in 1947 and 1948 (Thomson 1952). Seed oysters from Sendai, Kummamoto and Hiroshima in Japan (the latter is a known source of $G$. catenatum; Matsuoka \& Fukuyo 1994) were acclimatised in Pittwater (shallow, 1 to $2 \mathrm{~m}$ depth, tidal inlet) which today is the most productive oyster farming area in Tasmania. The environmental conditions in Pittwater are not conducive to $G$. catenatum growth, however, and neither cyst stages nor motile plankton cells have ever been detected in this area. While a number of Japanese pests (e.g. a Balanus barnacle species) were inadvertently introduced at that time, the probability of this dinoflagellate having been successfully introduced at this early date $(1947-48)$ as opposed to after 1972 is low. In contrast, the probability of introduction of viable $G$. catenatum resting cysts via ships' ballast water is high. Approximately 120 million $t$ of foreign ballast water are discharged in Australian ports every year, with approximately half the amount originating from Japan. A number of toxic dinoflagellate strains have been successfully cultured from this source (Hallegraeff \& Bolch 1991) and G. catenatum cysts have been confirmed from 4 ships entering Aus- tralian ports from both Japan and South Korea (Hallegraeff \& Bolch 1992). Ports at either Port Huon or Triabunna could have served as point sources of introduction into Tasmanian waters (Fig. 2). During the 1950s and terminating in 1960, ships which ballasted in England and other European ports regularly visited Port Huon, Tasmania, to load fruit. However, none of these ports of origin, except for infrequent arrivals from Spain and Portugal, is known to harbour G. catenatum. A small pulp mill in the Huon River, which started in 1962 and temporarily closed in 1982, attracted ships mainly from mainland Australia and New Zealand, but has also been serviced by a few South Korean vessels. Considering the small volumes of ballast water discharged and their major ports of origin (that is, long voyage times from Europe), the probability of a successful ballast water introduction directly into the Huon estuary is low. In contrast, a woodchip mill at Triabunna on the east coast of Tasmania started to operate in 1970, attracting ships from a number of Japanese ports including Ishinomaki, Kushiro, Yura and Yatsushiro (the latter is a known source of $G$. catenatum; Matsuoka \& Fukuyo 1994). These cargo vessels, each carrying $25000 \mathrm{t}$ of ballast water, arrived after short. direct, 16 to $21 \mathrm{~d}$ voyages from very similar climatic zones, thus increasing the probability of viable species transfer. A possible scenario therefore is the introduction of $G$. catenatum cysts near Triabunna soon after 1970 , the transport of viable cysts by currents from this site along the coast and into the Derwent and Huon River estuaries, and eventually the successful establishment of this species in these humus-laden estuaries. At its original point of introduction on the east coast of Tasmania, $G$. catenatum only blooms under exceptional climatological conditions (very long periods of calm stable weather) as were encountered in 1993 (Hallegraeff et al. 1995). Very similar introduction and spreading scenarios have been demonstrated for the Japanese seaweed Undaria pinnatifida (Sanderson 1990) and one has also been suggested for the Japanese starfish Asterias amurensis (Byrne et al. 1997). In June 1992 cysts and motile cells of $G$. catenatum were also detected of the coast of Melbourne (Sonneman \& Hill 1997) and in 1996 off Port Lincoln in South Australia (Hallegraeff unpubl. data). The results of molecular fingerprinting using RAPD-PCR indicate that the Tasmanian and South Australian populations are genetically identical (Bolch et al. in press). The possibility that the dinoflagellate populations on the Australian mainland could have been derived from the Hobart populations via ballast water transfer from coastal shipping is now being investigated. In a strict sense a mainland Australian origin for the Tasmanian population cannot be excluded, but in spite of extensive searches only small populations with limited via- 
bility have thus far been detected. Comparative molecular genetic fingerprinting is also in progress on Tasmanian and overseas dinoflagellate populations (notably focusing on Japan, Korea, Spain, Portugal; Bolch et al. in press) and ultimately this may be the only way to conclusively trace the precise source population.

Until the present investigation, an endemic Tasmanian origin for Gymnodinium catenatum could not be excluded. The sudden appearance of the cyst of this species in sediments after 1972 (or even after 1937 if the deepest cysts are not thought to be bioturbated) implies an introduction at or after this date from elsewhere. This result validates observational data of the absence of the motile dinoflagellate stage in Tasmanian waters prior to 1980 . The most likely method of introduction appears to have been via ballast water discharge either from northeastern Asian ports or less likely European ports. The methods described herein have wide application in addressing the problem of an apparent global increase and spread of harmful algal blooms (Anderson 1989, Smayda 1990, Hallegraeff 1993).

Acknowledgements. We thank Mr Chris Bolch, University of Tasmanıa, for help in collecting the first sedıment core and Dr Stephen Short, previously at Australian Nuclear Science Technology Organisation (ANSTO), for hus contribution to sediment dating at an early stage of the investigation. $\mathrm{Mr}$ Robert Chisari, ANSTO, is thanked for meticulously preparing the ${ }^{226} \mathrm{Ra}$ and ${ }^{210} \mathrm{Po}$ alpha spectrometry sources and $\mathrm{Mr}$ Greg Elliot, ANSTO, is thanked for performing the initial ${ }^{137} \mathrm{Cs}$ analyses. Mr Chris Bolch and Drs Pat Quilty and Don Anderson offered suggestions for improving an earlier version of the manuscript. This study was partially supported by a University of Tasmania small ARC grant and the ${ }^{210} \mathrm{~Pb}$ and ${ }^{137} \mathrm{Cs}$ analyses were supported by an AINSE grant (1995).

\section{LITERATURE CITED}

Anderson DM (1989) Toxic algal blooms and red tides: a global perspective. In: Okaichi T, Anderson DM, Nemoto $T$ (eds) Red tides: brology, environmental science and toxicology. Elsevier, Amsterdam, p 11-16

Anderson DM, Jacobson DM, Bravo I, Wrenn JH (1988) The unique, microreticulate cyst of the naked dinoflagellate Gymnodinium catenatum.J Phycol 24:255-262

Baldwin RP (1987) Dinoflagellate resting cysts isolated from sediments in Marlborough Sounds, New Zealand. NZ J Mar Freshwat Res 21:543-553

Blackburn Sl, Hallegraeff GM, Bolch CJ (1989) Vegetative reproduction and sexual hfe cycle of the toxic dinoflagellate Gymnodinum catenatum from Tasmania, Australia. J Phycol 25:577-590

Bolch CJ, Blackburn SI, Hallegraeff GM, Vaillancourt R (in press) Molecular genetic variation among different global populations of the toxic dinoflagellate Gymnodinium catenatum revealed by RAPD-PCR. In: Reguera B, Blanco J, Fernandez ML, Wyatt $T$ (eds) Proc 8th Int Conf Toxic Algae, Vigo, Spain
Bolch CJ, Hallegraeff GM (1990) Dinoflagellate cysts from Recent marine sediments of Tasmania, Australia. Bot Mar 33:173-192

Byrne M, Morrice MG, Wolf B (1997) Introduction of the northern Pacific asteroid Asterias amurensis to Tasmania: reproduction and current distribution. Mar Biol 127 $673-685$

Craib JS (1965) A sampler for taking short undisturbed marine cores. J Cons Perm Int Explor Mer 30:34-39

Dale B (1989) Dinoflagellate blooms: a geological perspective. 4 th Int Conf Toxic Marine Phytoplankton, Abstracts. Dept of Marine Ecology, University of Lund, p 51

Eakıns JD, Cambray RS, Chambers KC, Lally AE (1984) The transfer of radionuclides to Brothers Waters. In: Haworth EY, Lund. JWG (eds) Lake sediments and environmental history. University of Minnesota Press, Minneapolis, p 125-144

Evitt WR (1985) Sporopollenin dinoflagellate cysts: their morphology and interpretation. American Association of Stratigraphic Palynologists Foundation, Austın, TX

Glew JR (1989) A new type of mechanism for sediment samples. J Paleolimnol 2:241-243

Hallegraeff GM (1993) A review of harmful algal blooms and their apparent global increase. Phycologia 32:79-99

Hallegraeff GM, Bolch CJ (1991) Transport of toxic dinoflagellate cysts via ships' ballast water. Mar Pollut Bull 22: $27-30$

Hallegraeff GM, Bolch CJ (1992) Transport of diatom and dinoflagellate resting spores in ships' ballast water: implications for plankton biogeography and aquaculture. J Plankton Res 14:1067-1084

Hallegraeff GM, MCCausland MA, Brown RK (1995) Early warning of toxic dinoflagellate blooms of Gymnodinium catenatum in southern Tasmanian waters. J Plankton Res $17: 1163-1176$

Hallegraeff GM, Stanley SO, Bolch CJ, Blackburn SI (1989) Gymnodinum catenatum blooms and shellfish toxicity in Southern Tasmania, Australia. In: Okaichi $T$, Anderson DM, Nemoto $T$ (eds) Red tides: biology, environmental science and toxicology. Elsevier, Amsterdam, p 75-78

Hallegraeff GM, Steffensen DA. Wetherbee R (1988) Three estuarine Austratian dinoflagellates that can produce paralytic shellfish toxins. J Plankton Res 10:533-541

Hallegraeff GM, Sumner CE (1986) Toxic plankton blooms affect shellfish farms. Aust Fish 45:15-18

Jones R (1978) Why did the Tasmanians stop eating tish? In: Gould RA (ed) Explorations in ethno-archaeology. Albuquerque Press, Albuquerque, p 11-47

Keafer BA, Buesseler KO, Anderson DM (1992) Burial of living dinoflagellate cysts in estuarine and nearshore sediments. Mar Micropaleontol 20:147-161

Matsuoka K, Fukuyo Y (1994) Geographical distribution of the toxic dinoflagellate Gymnodinium catenatum Graham in Japanese waters. Bot Mar 37:495-503.

McMinn A (1989) Late Pleistocene dinoflagellate cysts from Botany Bay, NSW, Australia. Micropaleontology 35:1-9

McMinn A (1990) Recent dinoflagellate cyst distribution in eastern Australia. Rev Palaeobot Palynol 65:305-310

McMinn A (1991) Recent dinoflagellate cysts from estuarjes on the central New South Wales coast. Micropaleontology 37:259-287

McMinn A (1992a) Pliocene through Holocene dinoflagellate cyst biostratigraphy of the Gippsland Basin, Australia. In: Head MJ, Wrenn JH (eds) Neogene and Quaternary dinoflagellate cysts and acritarchs. American Association of Stratigraphic Palynologists Foundation, Dallas, p $147-161$ 
McMinn A (1992b) Neogene dinoflagellate distribution in the eastern Indian Ocean from Leg 123, Site 765. In: Gradstein FM et al. (eds) Proc ODP, Sci Results, 123. (Ocean Drilling Program), College Station, TX, p 429-442

Neale JL, Walker D (1996) Sampling sediment under deep warm. water. Quat Sci Rev 15:581-590

Nordberg K, Bergsten H (1988) Biostratıgraphic and sedimentological evidence of hydrographic changes in the Kattegat during the latter part of the Holocene. Mar Geol 83: $135-158$

Oldfield F, Appleby PG (1984) Empirical testing of ${ }^{210} \mathrm{~Pb}$-dating models. In: Haworth EY, Lund JWG (eds) Lake sediments and environmental history. University of Minnesota Press, Minneapolis, p 93-124

Oshima Y, Hasegawa K, Yasumoto T, Hallegraeff GM, Blackburn SI (1987) Dinoflagellate Gymnodinium catenatum as the source of paralytic shellfish toxins in Tasmanian shellfish. Toxicon 25:1105-1111

Sanderson C (1990) A preliminary survey of the distribution of the introduced macroalga Undaria pinnatifida (Harvey)

Editorial responsihility Otto Kinne (Editor),

Oldendorf/Luhe, Germany
Suringer on the east coast of Tasmania, Australia. Bol Mar $33: 153-157$

Sarjeant WAS (1974) Fossil and living dinoflagellates. Academic Press, London

Smayda TJ (1990) Novel and nuisance phytoplankton blooms in the sea: evidence for a global epidemic. In: Graneli $\mathrm{E}$, Sundstrom B, Edler L, Anderson DM (eds) Toxic marine phytoplankton. Elsevier, Amsterdam, p 29-40

Sonneman JA, Hill DRA (1997) A taxonomic survey of cystproducing dinoflagellates from the coastal waters of Victoria, Australia. Bot Mar (in press)

Thomson JM (1952) The acclimatization and growth of the Pacific oyster (Gryphaea gigas) in Australia. Aust J Mar Freshwat Res 3:64-73

Wood EJF (1964) Studies in microbial ecology of the Australian region. 5. Microbiology of some Australian estuaries. Nova Hedwigia 8:461-527

Zuo Z (1992) Dynamic behavoir of ${ }^{210} \mathrm{~Pb},{ }^{210} \mathrm{Po}$ and ${ }^{137} \mathrm{Cs}$ in coastal and shelf environments. PhD thesis, University of Utrecht

Submittcd: Scptomber 9, 1997; Accepted: October 15, 1997 Proofs received from author(s): December 22, 1997 